\title{
REPRESENTAÇÕES DOS MOVIMENTOS ESTUDANTIS BRASILEIROS NA IMPRENSA DIÁRIA DURANTE O ANO DE 1968. DE CALABOUÇO À MISSA DO SÉTIMO DIA ${ }^{1}$
}

DOI: http://dx.doi.org/10.1590/2236-3459/76888

\author{
José Luis Hernández Huerta \\ Universidad de Valladolid, Palencia/Castilla y León, España
}

$\cos 80$

\begin{abstract}
Resumo
O fenómeno global dos movimentos estudantis desenvolvidos durante o longo ano de 1968 assumiu contornos particulares no Brasil. Entre outros, este setor da comunidade universitária, em crescente processo de politização desde princípios da década, especialmente a partir da ditadura militar (1964), revelou-se um grupo social, cultural e político na vanguarda da resistência à mesma, capaz de amplas motivações e de incidir na política geral do país. Neste artigo aprofundam-se os imaginários sociais e as comunidades imaginadas construídos pela imprensa diária brasileira em torno das mobilizações estudantis desenvolvidas durante o primeiro trimestre de 1968, centrando a atenção nos sucessos de Calabouço, a sua onda expansiva e a Missa do Sétimo Dia. O objetivo é analisar os discursos construídos à volta destes eventos na esfera pública, as motivações e as reivindicações dos estudantes, os espaços, tempos e as intensidades das suas ações, assim como as correntes de opinião pública geradas pelas linhas editoriais da imprensa.

Palavras-chave: novos movimentos sociais, universidade, estudantes, 1968, opinião pública.
\end{abstract}

\section{REPRESENTATIONS OF BRAZIL'S STUDENT MOVEMENTS IN THE DAILY PRESS IN 1968. FROM CALABOUÇO TO THE SEVENTH DAY MASS}

\begin{abstract}
The global phenomenon of the student movements carried out during the long year of ' 68 had very particular characteristics in Brazil. Amongst other things, this sector of the university population - which had been embroiled in an intensifying process of politicization since the beginning of the decade, especially since the beginning of the military dictatorship (1964) - emerged as a social, cultural and political group at the very forefront of the resistance to the dictatorship, capable of ample mobilization, and of influencing the country's general policies. This article investigates the social ideologies and the imagined communities painted by the daily press in Brazil about the student mobilizations carried out during the first trimester of 1968, focusing on the events in the Calabouço restaurant, the shockwave caused by them and the Seventh Day Mass. The

\footnotetext{
${ }^{1}$ Esta investigação foi financiada pelo programa Ayudas del Plan de Movilidad del Personal Investigador. Convocatória 2016 da Universidad de Valladolid (Espanha) y desenvolvida no âmbito do Programa de PósGraduação em Educação e da atividade da linha de investigação Teorias e Culturas em Educação da Pontifícia Universidade Católica do Rio Grande do Sul (Porto Alegre, Brasil). Faz parte, igualmente, de um projeto mais amplo, que tem como objetivo analisar os processos de construção de imaginários pedagógicos coletivos através da imprensa diária em tempos de mudança política e social na Europa Mediterrânica e Ibero-América, desenvolvido pelo Grupo de Investigação da Universidade de Valladolid (Espanha) Ágora de Educación (http://www.agoradeeducacion.com).
} 
objective is to analyze the discourse produced about these events in the public sphere, the students' motivations and demands, the spaces, times and intensities of their actions, and the streams of public opinion generated by the press's publication choices.

Keywords: new social movements, university, students, 1968, public opinion.

\title{
REPRESENTACIONES DE LOS MOVIMIENTOS ESTUDIANTILES BRASILEIROS EN LA PRENSA DIARIA DURANTE EL '68. DE CALABOUÇO A LA MISA DEL SÉPTIMO DÍA
}

\section{Resumen}

El fenómeno global de los movimientos estudiantiles desarrollados durante el largo '68 tomó rasgos particulares en Brasil. Entre otras cosas, este sector de la población universitaria, en creciente proceso de politización desde inicios de la década, especialmente a partir de la dictadura militar (1964), se reveló como un grupo social, cultural y político a la vanguardia de la resistencia frente a ésta, capaz de amplias movilizaciones y de incidir en la política general del país. En este artículo se profundiza en los imaginarios sociales y las comunidades imaginadas construidos por la prensa diaria brasileira en torno a las movilizaciones estudiantiles desarrolladas durante el primer trimestre de 1968, centrando la atención en los sucesos de Calabouço, su onda expansiva y la Misa del Séptimo Día. El objetivo es analizar los discursos construidos alrededor de estos eventos en la esfera pública, las motivaciones y los reclamos de los estudiantes, los espacios, tiempos e intensidades de sus acciones, así como las corrientes de opinión pública generadas por las líneas editoriales de la prensa.

Palabras clave: nuevos movimientos sociales, universidad, estudiantes, 1968, opinión pública.

\section{LES REPRÉSENTATIONS DES MOUVEMENTS D'ÉTUDIANTS AU BRASIL DANS LA PRESSE QUOTIDIENNE EN 1968. DU CALABOUÇO A LA MESSE DU SEPTIĖME JOUR}

\begin{abstract}
Résumé
Le phénomène global des mouvements d'étudiants qui ont eu lieu pendant la longue année de ' 68 a pris des particularités au Brasil. Entre autres choses, ce secteur de la population universitaire - qui avait été impliqués dans un processus de politisation croissante dès le début de la décennie, surtout depuis l'établissement de la dictature militaire (1964) - a émergé en tant que groupe social, culturel et politique à l'avant-garde de la résistance au régime dictatorial, capable de produire une ample mobilisation, et d'influer sur la politique général du pays. Cet article enquête sur les idéologies sociales et les communautés imaginaires dépeintes par la presse quotidienne au Brasil autour des mobilisations étudiantes pendant le premier trimestre de 1968, mettant en relief les évènements au restaurant Calabouço, l'onde de choc qu'ont provoqué ces évènements, et la Messe du Septième Jour pour la victime. Objectif: analyser les discours produit autour de ces évènements dans la sphère publique; les motivations et revendications des étudiants; les lieux, temps and intensités de ses actes; et les trains de pensées dans l'opinion publique généré par les lignes éditoriales adoptées par la presse.

Mots-clés: nouveaux mouvements sociaux, 'université, les étudiants, 1968, l'opinion publique.
\end{abstract}




\section{Introdução}

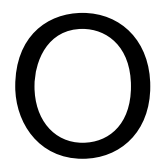

$s$ longos anos 60 do século XX, marcados pelos inúmeros e variados rostos da Guerra Fria, foram tempos de mudanças políticas, sociais e culturais à escala planetária. Entre outros, a década caracterizou-se pela intensificação da vida dos movimentos sociais, culturais e políticos já existentes, particularmente os vinculados aos setores operários e agrícolas e pelo surgimento de outros "novos" - ecológicas, feministas, de vizinhos, gays e lésbicas, consumidores, pró-direitos civis, pacifistas, etc. -, que pretendiam fazer do mundo algo mais habitável, livre, justo e solidário. Os "novos movimentos sociais" ou "movimentos alternativos", introduziram algumas variáveis nas suas argumentações e mobilizações que transcendiam as formas, as motivações e as reivindicações tradicionais da luta dos trabalhadores e que refletiam as mutações nos estilos de vida social e cultural que se estavam a produzir. Assim, em primeiro lugar, incorporaram no seu discurso uma crítica ideológica ao conceito de modernidade e às teorias e modelos de desenvolvimento prevalentes. Em segunda instância, desenvolveram a noção e a experiência de identidades coletivas. Para além disso, envolveram e puseram em movimento diversos e variados intervenientes, para além da questão proletária. Em quarto lugar, transformaram os estilos e modos de se organizarem, agora mais descentralizados e participativos, baseados na solidariedade interpessoal, em práticas de comunicação mais fluidas, na toma de decisões de forma coletiva e consensual e da redistribuição dos bens sociais. Por último, desenvolveram a sua atividade num - então moderno - espaço situado entre o público e o privado, que incorporou estilos de vida próprios desta esfera na outra, transformando as suas motivações em objetivos em algo legítimo, mediante a praxis e os feitos consumados, pelos intervenientes e pelas instituições políticas oficiais: o espaço das políticas não institucionais. (HALL, 1970; MARWICK, 2005; OFER; GROVES, 2016; OFFE, 1985).

Alguns destes movimentos obtiveram um impacto significativo na educação das regiões geográficas onde exerceram a sua influência. Em alguns casos, possibilitaram, entre outros, a abertura e modernização dos sistemas educativos, a introdução nos mesmos de algumas doses de equidade, a sua progressiva democratização, o surgimento de outras formas de educação à margem do oficial, mais vivas, dinâmicas e críticas, com um marcado carácter social, por vezes, popular, especialmente na América Latina. (BRUNO-JOFRÉ, 2016; GROVES, 2014; IGELMO ZALDÍVAR, 2016).

Os movimentos de estudantes universitários que se desenvolveram à escala planetária durante o longo '68 (HERNÁNDEZ HUERTA, 2018) foram um exemplo significativo das formas que adotaram os novos movimentos sociais e uma genuína manifestação dos jovens em ação, de uma "nova geração" capaz de ouvir "o tic-tac" do futuro-presente, caracterizada em todas as partes "pela sua pura coragem, por uma surpreendente vontade de agir e por uma não menos surpreendente confiança na possibilidade da existência mudanças" e pelo que fez da revolução global dos estudantes "um dos acontecimentos totalmente imprevistos" do século XX: o feito de se tratar de uma "revolução estudantil quase exclusivamente inspirada por considerações morais". Apesar deste substrato comum, a variedade desses movimentos foi ampla. As particularidades que adquiriram dependeram dos traços culturais, sistemas políticos, diretrizes na Guerra Fria, conjunturas socioeconómico e idiossincrasias várias instaladas nas regiões geopolíticas onde se desenvolveram e, dentro destas, diferenciaram-se de universidade para 
universidade, dependendo das culturas académicas, das tradições municipais e dos equilíbrios de forças sociais, Na América Latina, particularmente na Argentina, no Brasil, no México e no Uruguai, as reivindicações dos jovens universitários, o mesmo que em outras latitudes, contemplaram o aumento da ideia de democracia, a revisão do conteúdo histórico da mesma e a posta em prática de uma estilo mais participativo. Contudo, adquiriram outras nuances, uma vez que se viram notavelmente condicionados, entre outros, devido à pobreza estrutural e à instabilidade política da região, os planos de desenvolvimento económico, social e cultural implementados pelos EUA na região, a consciência do alcance e dos efeitos da revolução cubana, os recentes ventos da reforma do Vaticano II, a teologia da liberação, o incipiente pós-colonialismo, a questão indígena e afroamericana, o marcado elitismo socioeconómico, o caráter autoritário e o desfasamento das instituições de ensino superior e a aparição de formas e estilos críticos de socialização e extensão das culturas à margem das vias institucionais. (CAGNOLATI, 2011; CAREY, 2016; CARRILLO-LINARES, 2015; DELGADO; GAUTREAUX; ROSS, 2016; MARKARIAN, 2017; MARWICK, 2005; ROMÃO, 2008).

Efetivamente, o Brasil, que vivia sob uma ditadura militar desde 1964, não ficou à margem da corrente internacional. Pelo contrário, neste espaço geopolítico o movimento estudantil foi, por um lado, um dos setores mais vivos, dinâmicos e comprometidos com a modernização da Universidade brasileira e, por outro lado, significou uma das mais representativas formas de resistência frente à ditadura militar, iniciada quatro anos antes. Durante 1968, particularmente de março a outubro, as mobilizações e atividades dos estudantes foram especialmente intensas e estenderam-se por boa parte da geografia universitária o país, destacando os focos de Rio de Janeiro e São Paulo (HERNÁNDEZ HUERTA, 2017). Todavia, tais atividades estudantis tiveram o seu fim em dezembro, depois do Ato Institucional n. 5 (Al-5), que inaugurou uma nova etapa na evolução da ditadura, marcada por uma política de repressão e censura mais intensas e de mais largo espectro.

Neste artigo analisam-se representações na esfera pública - onde "unicamente se tolera o que é considerado apropriado, digno de ser visto ou ouvido" (ARENDT, 1993) - dos estudantes universitários brasileiros construídas e disseminadas pela imprensa diária durante o ano de 1968. Presta-se especial atenção às motivações, às reivindicações e às aspirações da juventude universitárias, à sua capacidade de mobilização social, integração dos intervenientes políticos alternativos e negociação com o Estado, os espaços, os tempos e as intensidades das suas ações, e as correntes de opinião geradas pela imprensa diária através das narrativas elaboradas a partir dos testemunhos, opiniões e interesses próprios, dos seus protagonistas e dos restantes intervenientes sociais implicados na questão estudantil. Além da crónica, que permite estabelecer os fatos, a intensidade, a frequência e a magnitude das formas públicas de resistência dos estudantes à ditadura, através desta pesquisa aprofunda-se, fundamentalmente, a análise ideológica e crítica dos discursos (VAN DIJK, 1996, 1999) criados e canalizados pelo quarto poder, aqueles que, profundamente mediatizados e submetidos, no caso do Brasil, aos próprios processos de linguagem totalitária (KLEMPERER, 2001; ROSÚA, 2001), chegaram ao cidadão comum alheio ao discurso técnico-científico - e que, verdade ou não, passaram a fazer parte da arquitetura social do pensamento.

Assim, o que interessa, aqui e agora, não é tanto a verdade, se não aquela que, sem sê-lo, o pareceu, essa aparência - "algo que veem e ouvem os outros tal como nós" 
(ARENDT, 1993) - que constitui a realidade e que configura a forma na qual as pessoas comuns tecem as redes da memória coletiva - recordações comuns partilhadas por grupos de pessoas filtrados pelas experiências e aspirações de cada individuo (HALBWACHS, 2004; RICOEUR, 2010) - e constroem o imaginário social, isto é, o modo segundo o qual

[...] imaginam a sua existência social, o tipo de relações que mantêm umas com as outras, o tipo de coisas que acontece entre elas, as expectativas que se cumprem habitualmente e as imagens e ideias normativas mais profundas que estão subjacentes a estas expectativas [...] que torna possíveis as práticas comuns e um sentimento de legitimidade amplamente partilhado. (TAYLOR, 2006).

Uma característica dos jornais é que estes processos se desenvolvem no seio de amplas comunidades imaginadas onde os indivíduos estabelecem diálogos sem o encontro do outro - nem a possibilidade do mesmo - e as realidades se justapõem no "avanço sustentado do tempo homogéneo, vazio", um "mundo imaginado" que, não obstante, "está visivelmente enraizado na vida diária". (ANDERSON, 1993).

O período de análise compreende o primeiro trimestre de 1968, contudo destacase o compreendido entre o dia 28 de março, data na qual se desenvolveram os sucessos de Calabouço (Rio de Janeiro), e o 6 de abril do mesmo ano, dia em que a imprensa, depois de um período de intensos conflitos entre as forças públicas de segurança e os estudantes universitários, que encontrou o seu ponto culminante depois da Missa do Sétimo Dia, anunciou que os últimos tinham terminado e que o ambiente tinha regressado à calma. Tais eventos são de particular interesse, principalmente por duas razões: primeiro, eram locais com repercussão a nível nacional e geravam impacto mediático e, portanto, exerceram alguma violência sobre o imaginário social; Em segundo lugar, convertidos em símbolos da resistência à ditadura, tornaram-se num elemento recorrente na esfera pública e passaram a formar parte da mitologia revolucionária estudantil, especialmente expressa durante a Passeata dos Cem Mil e nas circunstâncias que a rodearam, já durante o mês de junho de 1968. E as fontes documentais estão selecionadas para tais propósitos, estão constituídas pelos editoriais, artigos de opinião, crónica, entrevistas, notícias e fotografias, - um total de 81 elementos - sobre o tema objeto de estudo que apareceram publicadas no Correio do Povo, o diário mais antigo e de maior difusão na região do Rio Grande do Sul (Brasil), representativo dos detores liberal-conservadores.

\section{A universidade brasileira durante a ditadura militar (1964-1968): modernização, limpeza e resistência estudantil}

No Brasil, o mês de abril de 1964 marcou o início de uma larga ditadura cívicomilitar que durou mais de duas décadas. Em volta dos golpistas militares formou-se uma coligação de setores - liberais, conservadores, reacionários, nacionalistas, autoritários e reformistas moderados - que pretendiam modernizar o país, fazer frente ao consumismo, regenerar espiritualmente o tecido social e reverter as reformas de governos anteriores, particularmente as adotadas por João Goulart, que tinham adquirido um marcado caráter social, democrático e popular. Essas pretensões materializaram-se em políticas distintas. Por um lado, enfatizaram-se as dimensões económica e administrativa da ideia de modernização, na linha dos planos de desenvolvimento para a América Latina marcados pelos EUA, segundo os quais a industrialização, a melhora de infraestruturas e o 
crescimento económico do país conseguiriam travar o avanço do comunismo, consolidar a democracia liberal e manter a ordem e a paz sociais. Por outro lado, realizou-se uma forte defesa de valores como pátria, família e religião (cristã), que passaram a estar sempre presentes, incluindo o sistema nacional de educação, que se orientou para estilos cívicos de acordo com esses princípios. Além disso, o jogo político democrático, de facto, deixou de sê-lo, e as suas instituições foram, desde o início, vazias de significado e conteúdo, passando a ser cenários onde a representação política adquiria um permanente caráter orwelliano. E, paralelamente, puseram-se em marcha mecanismos para neutralizar, através de diferentes formas de controlo, vigilância, censura e violências de distinto tipo, aos setores da população mais progressistas, particularmente aos socialistas e comunistas, e a todos aqueles que, simplesmente, discordam das programáticas do regime militar; o que ficou conhecido como Operação Limpeza. (MAIA, 2013; NETTO, 2014; ROCHA, 2015; ROSÚA, 2001; VIEIRA, 2015).

A universidade, por sua vez, foi valorizada por parte do governo militar como uma peça chave para os seus planos de desenvolvimento e modernização do país. E para tal, primeiro era necessário fazer isso mesmo com as próprias instituições de ensino superior. Este era um sentimento partilhado por todos os setores da universidade, desde os progressistas radicais, até aos liberal-conservadores. Todos consideravam que era necessário potenciar a investigação, de modo que a universidade fosse capaz de gerar e disseminar conhecimento útil e necessário para o progresso nacional. Do mesmo modo, foi necessário optar por estruturas organizacionais mais ágeis e eficientes, o que implicava substituir o sistema clássico de cátedras, pelo sistema moderno de departamentos, ao estilo norte-americano, capaz de dinamizar e canalizar as atividades de ensino e pesquisa, bem como democratizar a gestão de instituições; durante o governo Goulart, a Universidade de Brasília (UB) tornou-se no primeiro centro a experimentar este modelo de gestão. E, em terceiro lugar, era imperativo mudar o modo de acesso aos estudos universitários, adaptando-o ao fenómeno internacional da universidade das massas; Isso gerou no Brasil o que se chamou o problema do "excedente", ou seja, aquele aluno que, após ter passado os exames e demonstrado a sua adequação, não poderia exercer o seu direito de estudar, devido à escassez de locais escolares. Não obstante, apesar de tais sinergias, os grupos progressistas demarcavam-se do resto em duas questões: por um lado, o respeito pelo caráter e pelos fins atribuíveis à universidade, considerada como um espaço de liberdade para a discussão e pensamento crítico e como uma instituição de caráter popular, solidária com as causas sociais e na vanguarda das transformações socialistas; Por outro lado, reclamava-se uma profunda reforma dos modos de participação da comunidade universitária na gestão dos centros, incrementando substancialmente o grau de representação estudantil em todos os órgãos do colegiado. (CUNHA, 2007; MOTTA, 2014).

Desde abril de 1964, até novembro de 1968, os debates acerca da reforma universitária giraram em torno desses assuntos. Todavia, à medida que o tempo avançava, as abordagens pragmáticas e eficientes de liberais e moderados iam adquirindo mais força e peso. Assim, impulsionaram-se os estudos e a investigação nas áreas das ciências aplicadas e tecnologias, em detrimento das sociais e humanas, que não eram produtivas, mas até então as mais concorridas. A política universitária internacional voltou-se para os países ocidentais, particularmente para os EUA; Isto cristalizou, em meados de 1965, nos acordos entre o Ministério da Educação (MEC) e a United States Agency for International 
Development (Usaid), que contemplou a tradução e publicação de livros, a reestruturação dos programas de ensino, assim como a provisão de fundos e estratégias de planificação para a reforma universitária e dos outros graus do ensino. E, seguindo a lógica da redução da despesa pública, especialmente nas áreas da educação e sanidade, foi-se introduzindo no discurso a ideia de cobrar mensalidades aos estudantes. Esses debates foram, pouco a pouco, passando ao plano da realidade através de algumas reformas legais de caráter parcial, tais como Decreto-Lei $n .53$ (18 de novembro de 1966), a reforma da Constituição da República Federativa do Brasil (24 de janeiro de 1967) e o complemento do mesmo, o Decreto-Lei n. 252 (28 de fevereiro de 1967). (ÉSTHER, 2015).

Contudo, a universidade era também vista com preocupação e desconfiança por parte do governo militar, até chegar a converter-se num assunto de segurança nacional. Por serem espaços de pensamento livre e crítico, as universidades foram valorizadas como potenciais pontos de resistência face ao novo regime. Para além disso, eram percebidas como um dos principais focos de infiltração comunista e de ideias radicais e subversivas de todo o tipo, uma posição que o comunismo procurava ganhar através de políticas e táticas de recrutamento de estudantes e, especialmente, de professores, visto que, devido à sua posição, poderiam chegar a um público mais vasto. Também se considerava que as universidades brasileiras, salvo exceções, se tinham convertido em lugares nos quais se permitiam licenciosamente comportamentos tidos pelo regime como desviados e inaceitáveis, tais como práticas sexuais livres e despreocupadas ou o consumo de drogas leves, situações que para alguns dos setores da população significavam degradação dos valores pátrios, familiares e religiosos e o prolegómeno da militância comunista.

Assim, recém-iniciada a ditadura, de forma progressiva, as reitorias universitárias foram intervencionadas e a Operação Limpeza aplicada a professores e estudantes. $\mathrm{O}$ resultado foi que houve um bom número de estudantes que foram expulsos da universidade e impedidos de continuar os seus estudos e uma considerável quantidade de professores afastados do seu cargo e encaminhados, por obrigação ou por precaução, para o exílio exterior, onde não poucos prosseguiram a sua carreira; Para tentar reverter este efeito não desejado, o governo militar pôs em marcha o que se chamou de Operação Retorno, que consistiu em facilitar o regresso de docentes e investigadores que tinham saído do país para evitar a Operação Limpeza. Também houve abundantes casos de estudantes e professores detidos, interrogados e submetidos a duras torturas psicológicas e a pressões físicas, que consistiram, na maioria das vezes, em contusões, geralmente na cara, pelo menos até à promulgação do Ato Institucional n. 5 (Al-5), em dezembro de 1968; A partir de então, a violência e a tortura de todo o tipo cobraram uma nova dimensão, tanto pela intensidade como pela frequência e extensão. (FAGUNDES, 2013; FERNANDES, 2015).

Os estudantes foram o setor social e político universitário ao qual o governo militar prestou particular atenção, até ao ponto de inclui-os na agenda de segurança nacional, pois, por um lado, contavam com uma vasta trajetória como protagonistas dos palcos públicos e políticos do Brasil, especialmente durante o governo de Goulart, e, por outro lado, eram considerados como sujeitos mais suscetíveis e permeáveis face à infiltração comunista. Efetivamente, em 1964, os jovens brasileiros, especialmente os universitários, seguindo a tendência internacional, encontravam-se imersos num progressivo processo de politização em direção ao espetro político da esquerda, o que os constituía como um dos setores da população mais recetivos às ideias progressistas, radicais e marxistas- 
socialistas. Assim, maioritariamente, sentiam-se atraídos por algum tipo indefinido de socialismo capaz de levar a cabo as reformas que o Brasil necessitava, baseadas na justiça e equidade social; Por sua vez, os que se mostravam mais próximos ao estilo soviético constituíam uma minoria pouco significativa, ao contrário das apreciações do regime militar. Da mesma forma, manifestavam insatisfação, indignação e notável preocupação face aos problemas agrícolas do Nordeste do país, mais que os próprios agricultores, protagonistas da sua condição e situação. Por sua vez, as propostas liberais e o modelo de desenvolvimento capitalista suscitavam nos mesmos pouco entusiasmo e menos simpatia, o que os convidava a sentirem-se atraídos e solidários com os discursos e políticas antiimperialistas, especialmente a partir de 1965, após os mencionados acordos MEC-Usaid. No entanto, este processo de ideologização dos estudantes universitários, ao contrário das convicções do governo militar, desenvolveu-se de maneira independente, apesar da influência dos professores, que em alguns casos se viram seduzidos e/ou arrastados pelas abordagens dos seus discípulos. (MOTTA, 2014).

A progressiva politização da juventude brasileira traduziu-se, no ambiente universitário, numa forte, ampla e ativa organização dos estudantes, que combinou motivações de índole política e social com as específicas e circunscritas ao âmbito universitário, como foram a modernização das instituições de ensino superior, a democratização das mesmas e a extensão deste nível de ensino. Desde 1960, até à conclusão do golpe militar, liderados pela União Nacional dos Estudantes (UNE), que aglutinava tendências socialistas, comunistas, conservadores liberais e católicos, os estudantes universitários configuraram-se como uma força social, estabelecidas no meio académico, capaz de ter impacto na política geral universitária do país e com crescentes iniciativas e capacidade de ação. Progressivamente, reflexo do peso que iam adquirindo os setores progressistas no seio da UNE, o seu discurso foi acentuando o caráter social e político, mostrando um maior compromisso na luta de classes, solidarizando-se, especialmente, com as causas operárias e agrícolas. (CUNHA, 2016; FONTES; ALVES, 2013; FRANCO; SOUZA, 2013; MATTOS, 2014).

Os golpistas estavam a par deste panorama quando decidiram fazer-se ao poder. Razão pela qual a Operação Limpeza se viu reforçada com outras medidas, todas elas com tendência a desarticular e restringir o ímpeto do movimento estudantil. Por um lado, o governo exerceu sobre estes tipos distintos de repressão e violência. Deste modo, no dia 1 de abril de 1964, a sede central da UNE, situada no Rio de Janeiro, foi ocupada e incendiada, os principais líderes estudantis foram neutralizados, os projetos socioculturais paralisados e a própria organização desmantelada e proibida, sendo obrigada a passar à clandestinidade. (SANFELICE, 2015).

Por outro lado, tentou-se controlar toda a forma de organização ou associação de estudantes universitários. Para o efeito, promulgou-se a Lei Suplicy - Lei oㅜ 4.464, de 9 de novembro de 1964 -, através da qual se pretendia atender às demandas de participação e organização estudantil reivindicadas pelos setores liberais e moderados, neutralizar 0 caráter crítico e ideológico e a capacidade operativa dos estudantes e dar voz ao protagonismo a quem o governo considerava a "maioria silenciosa" Assim, a UNE foi substituída pelo Diretório Nacional dos Estudantes (DNE), os órgãos de participação estudantil relegados à finalidade de defender os interesses académicos dos estudantes, proibindo-se qualquer tipo de ação político-ideológica, greves e manifestações, e o voto 
dos estudantes nas suas organizações estabelecido como obrigatório, com a esperança de que aquela "maioria silenciosa" conseguisse vencer democraticamente os setores de esquerda.

Contudo a violência física, administrativa e simbólica exercida pelo governo sobre os estudantes universitários não fez mais do que acentuar e acelerar o processo de politização da juventude universitária. Após a fase mais dura e intensa da Operação Limpeza e após o choque inicial da mesma, os alunos gradualmente recuperaram a sua capacidade operacional, os líderes de esquerda assumiram o seu papel como tal nas principais organizações, incluindo UNE, e estas retomaram a sua atividade académica, política e social. Assim, por exemplo, a UNE, apesar do seu caráter clandestino continuou na vanguarda da resistência estudantil e logrou desenvolver os seus XXVIII e XXIX Congressos Nacionais, celebrados, respetivamente, em 1966 (Belo Horizonte) e 1967 (Valinhos) Durante o decurso destes eventos, o discurso dos estudantes foi adquirindo um vincado caráter de classe e a organização oi tomando posições cada vez mais próximas à causa operária e agrícola. Além disso, projetou o XXX Congresso Nacional para 1968 (Ibiúna), mas este não chegou a realizar-se, devido à forte repressão militar. 800 Estudantes foram detidos, matriculados e conduzidos ao presídio de Tiradentes (São Paulo) e aos líderes mais evidentes, uma vez levados à cidade de Santos, foram-lhes instauradas auditorias militares. (FRANCO; SOUZA, 2013; POERNER, 2004; SANFELICE, 2015).

A resistência estudantil frente à ditadura passou do plano do discurso e do meio académico ao da ação e a desenvolver-se nos espaços públicos das áreas urbanas, especialmente das capitais e cidades que albergavam centros de ensino superior, de entre as que se destacaram Rio de Janeiro e São Paulo. A partir de 1965, até finais de 1968, de forma paulatina, as greves, ocupações e passeatas multiplicaram-se, intensificaram e ampliaram a sua capacidade de convocatória, tanto de estudantes como de outros intervenientes sociais, políticos e culturais. Assim, por exemplo, a primavera austral de 66 ficou conhecida como Massacre da Praia Vermelha, devido à forte repressão policial exercida, no dia 23 de setembro desse ano, sobre os estudantes para desalojar a antiga Faculdade de Medicina da Universidade Federal do Rio de Janeiro (UFRJ). As principais motivações dos protestos estudantis podem ser colocadas em dois grupos. As do primeiro referem-se a assuntos estritamente educativos, particularmente à questão universitária: o caráter público e gratuito da escola, a necessidade de dotar o bacharelato de um perfil profissional, o estilo e a orientação "fascista" do sistema educativo, a alfabetização do povo, os acordos MEC-Usaid, a Lei Suplicy, o problema dos "Excedentes", as iniciativas legislativas encaminhadas para a privatização do sistema universitário e o estabelecimento de mensalidades aos estudantes, e as detenções de alunos e docentes universitários, assim como a perseguição e tortura de alguns dirigentes estudantis. As do segundo grupo fizeram referência a espaços públicos, políticos e culturais mais amplos: os direitos humanos, o regresso às garantias constitucionais prévias ao golpe de estado, a questão operária e agrícola, a política económica do governo, a lei da greve, a revogação dos A-I, a promulgação de uma lei de amnistia, as liberdades de associação e filiação política e sindical, as eleições diretas, a guerra do Vietnam e a postura do Brasil a esse respeito, e a igualdade e solidariedade internacional. (FRANCO; SOUZA, 2013; POERNER, 2004; SANFELICE, 2015). 
Ações e reações deste tipo possibilitaram que os estudantes universitários adquirissem presença e protagonismo nas esferas públicas e isso implicou, por sua vez, que fossem incluídos entre os objetivos prioritários dos serviços de informação e segurança nacional. Também fez com que o governo tomasse outras iniciativas para além da repressão. Com a finalidade de neutralizar parte do discurso sociocultural mais crítico e comprometido e tentar conter as crescentes mobilizações, em julho de 1967, o governo, apoiando-se ao citado Decreto-Lei n. 252, pôs em marcha o Projeto Rondon - também conhecido como Operação Rondon -. (MOTTA, 2014).

Todavia este gesto não conseguiu diminuir a força das ações face à ditadura, desenvolvidas pelos estudantes. Pelo contrário, a revolução universitária não fez mais do que adquirir um novo impulso. Deste modo, a intensidade, a frequência e o impacto das passeatas e de outras formas resistência estudantis exerceram uma tal pressão sobre 0 governo que, em novembro de 1967, a Lei Suplicy foi revogada. A partir de então, essas receberam uma nova dimensão e a repressão um caráter mais virulento e agressivo, especialmente, entre março e outubro de 1968, particularmente em cidades como Rio de Janeiro ou São Paulo; também conseguiram convocar setores da sociedade mais amplos e que, por sua vez, dispunham de uma grande capacidade operativa, como era a Igreja Católica, que se mostrou abertamente simpatizante da causa estudantil. Exemplos significativos disso mesmo foram os acontecimentos que se desenvolveram a partir de Calabouço (Rio de Janeiro, março), os que antecederam a Passeata dos Cem Mil, a própria (Rio de Janeiro, junho) e os que resultaram no que ficou conhecido como a Batalha da Maria Antônia (São Paulo, outubro). (DE MORAES FREIRE, 2008; POERNER, 2004).

Tudo isto evidenciava que o regime militar era incapaz de conter a influência dos estudantes progressistas e reformistas sobre as estruturas universitárias, que a "maioria silenciosa" não cessava de aparecer e que as medidas de cooptação e repressão da população universitária eram pouco efetivas, o qual por sua vez, fazia transparecer à população a sensação de que o governo não conseguia manter a promessa de assegurar a ordem e a paz sociais, que tinha contribuído para legitimar o golpe de 1964.

Assim sendo, o governo considerou oportuno mudar de tática para tentar conter a resistência estudantil, procurando criar meios e circunstâncias à margem da pura e simples repressão. Então, seguindo a recomendação da chamada Comissão Especial Meira Mattos, criada em dezembro de 1967, decidiu-se acelerar o processo de reforma universitária. Em julho do ano seguinte, foi posto em funcionamento o Grupo de Trabalho para promover a Reforma Universitária (GTRU), que se encarregou, finalmente, de levar avante a Lei n.5.540, de 28 de novembro de 1968, que reformula os decretos anteriormente mencionados, clarificava o mandato constitucional e respondia, ao mesmo tempo, às necessidades de planificação dos militares e às exigências dos setores universitários liberais e moderados, o que a converteu num documento aceite por boa parte da comunidade universitária.

No entanto esta lei significou algo mais. Em primeiro lugar, assentou as bases sobre as quais se construiu a universidade moderna, competitiva e adaptada ao fenómeno de massas, modelo que perdurou durante meio século. Por outro lado, o nascente discurso da profissionalização do corpo de professores universitários, a especialização dos saberes, o incremento do financiamento da investigação e a abertura de mais espaços académicos, tais como novas universidades, propiciaram o desenvolvimento de um novo tipo de 
intelectual brasileiro, o "professor-investigador", que, desde inícios da década, se tinha começado a criar, e que teria, durante as décadas de 1970 e 1980, um protagonismo crescente na esfera pública do país. Em terceiro lugar, ao serem incorporadas ao texto legal boa parte das reivindicações estudantis, pelo menos dos ramos moderado e liberal, 0 contestatário movimento de estudantes foi socialmente deslegitimado e politicamente neutralizado; A partir de então, as manifestações e outras ações empreendidas por este setor da população universitária seriam consideradas algo de uma minoria radical e revolucionária. (CUNHA, 2016; FERNANDES, 2015; MOTTA, 2014; ROTHEN, 2006).

\section{Representações das mobilizações estudantis do ano de 1968 na esfera pública brasileira: de Calabouço à Missa do Sétimo Dia ${ }^{2}$}

O longo ano de 1968 foi coberto pela imprensa diária numa conjuntura mediática particular. Ao mesmo tempo que competia com a Televisão e fazia frente a uma forte crise económica e empresarial - 1 exemplar por cada 22 habitantes -, os jornais começavam a evidenciar o processo de modernização técnica, profissional e empresarial iniciado na década anterior e que culminou durante a seguinte. Inspirados no modelo norte-americano, os periódicos brasileiros incorporaram novos padrões discursivos e o ideal de objetividade, neutralidade e imparcialidade. Isto traduziu-se, entre outros, em novas secções informativas - reportagens, notas, notícias-, com uma linguagem impessoal, anónima e distante em relação à realidade de referência, que as diferenciavam dos artigos de opinião, colunas e editoriais, que continuaram com a sua habitual carga ideológica - em sentido lato -. Isto contribuiu para uma progressiva despolitização dos meios de comunicação de massas impressos, que se agravou durante a ditadura, devido à pressão exercida sobre os diários. (BARBOSA, 2007; RIBEIRO, 2006; SODRÉ, 2011).

Efetivamente, embora a imprensa inicialmente se tenha mostrado solidária com as motivações do golpe militar de 1964 e o tenha legitimado através das suas páginas, este setor da indústria da comunicação e informação rapidamente começou a conhecer de perto o rigor da ditadura. Desde o início, esta encarregou-se de controlar a imprensa através de estratégias de diferentes tipos. Por um lado, puseram-se em marcha táticas de repressão direta: perseguiram-se jornalistas, levaram-se a cabo ocupações policiais e militares dos locais de redação e, inclusive, fez-se uso da violência. Por outro lado, articularam-se mecanismos de coação indireta, cortando os fluxos de capital e financiamento, por exemplo, através da pressão a possíveis anunciantes. Além disso, estabeleceram-se estratégias de censura materializadas no sequestro de tiragens completas - que também tinham efeito económico - e na proibição direta, geralmente através de conversações telefónicas ou notas de papel, da publicação de determinadas notícias e informações. E, em fevereiro de 1967, promulgou-se uma nova lei de imprensa - Lei n. 5.250 - que unida às limitações impostas pela também normativa de segurança pública - Decreto-Lei n. 314, de 13 de março de 1967 -, frustrava o ideal de informação livre, veraz e objetiva, próprio do código deontológico da profissão. O resultado foi que, por um lado, surgiu um tipo de

\footnotetext{
2 Para aliviar o texto de citações e excessivas referências, apenas se consignam fontes documentais de onde retirem palavras textuais. Nos restantes casos, recomenda-se ao leitor interessado que consulte as seguintes edições de Correio do Povo, todas elas correspondentes ao ano de 1968: dias 5, 11, 12, 13, 16, 18, 28 e 30 de janeiro; 1, 7, 8, 10, 15, 18, 20 e 21 de fevereiro; 2, 6, 7, 9, 10, 11, 12, 13, 14, 15, 16, 17, 19, 21, 22, 23, 24, 26, 27, 29, 30 e 31 de março; e 2, 3, 4, 5, 7, 9 e 10 de abril. Tenha-se em consideração que, na maioria das vezes, numa mesma edição apareceram várias referências à questão estudantil universitária.
} 
imprensa alternativa, minoritária e de vida fugaz, que conseguiu escapar ao controlo e à censura das autoridades e que possibilitou o acesso a outras informações que os grandes meios de comunicação não queriam ou não podiam oferecer. Por outro lado, começou a funcionar um tipo de censura sem censura, a autocensura ou censura preventiva. Conseguida através das políticas do medo e da incerteza. A partir do A-I 5, foram impostas duras medidas de censura prévia, sanções aos periódicos e penas aos editores, redatores e colaboradores. (BARBOSA, 2007; ROMANCINI; LAGO, 2007).

De qualquer forma, a imprensa diária configurou-se como um dos principais espelhos públicos através do qual os cidadãos brasileiros acederam à atualidade quotidiana de uma realidade social e política mais ampla, ainda que também mais mediatizada. A questão universitária e, especialmente, as mobilizações estudantis, quer no Brasil quer noutros países, desenvolvidas durante ano de 68, ocuparam, desde o início, um espaço mediático significativo nos periódicos brasileiros, figurando, por vezes, na primeira página.

Durante o primeiro trimestre do ano, foram chegando notícias da atividade estudantil que, com motivações diversas, desde a defesa da liberdade de expressão, até à exigência de modernizar e democratizar a universidade, passando pela guerra do Vietnam, se estava a desenvolver pelo mundo - República Dominicana, Espanha, Argélia, Itália, Japão, Coreia do Sul, Polónia, Colômbia, EUA -. Estes jovens universitários foram apresentados como uma fonte de extrema conflitualidade, que desafiava a ordem e a paz sociais e promovia estilos de vida e ideais políticas de esquerda ou comunistas. A questão estudantil brasileira, por sua vez, centrou-se no mal-estar, nas greves e nas propostas geradas pela escassez de recursos ou mau estado das infraestruturas e, especialmente, pelo problema dos "excedentes", que, apesar das iniciativas de algumas universidades federais, não tinha solução satisfatória em vista, e nos desentendimentos entre estes e o governo durante as tentativas de negociação. Entretanto, este último procurava limpar a sua imagem pública, publicitando os avanços da Comissão Especial Meira Mattos, os êxitos do Projeto Rondon e a eficácia do sistema universitário, destacando o reconhecimento que a Unesco concedeu aos ensinos tecnológicos da Universidade de Brasília.

Contudo, no fim do mês de março, os tempos avançaram rapidamente e os locais onde se desenvolveu a ação foram diversificando. Uma pequena concentração estudantil, desenvolvida no dia 28 de março, motivada pela paralisação das obras da cantina universitária de Calabouço (Guanabara, Rio de Janeiro), foi a origem de uma série de acontecimentos que durante uma semana permitiram aos estudantes obter um lugar de destaque nas páginas dos diários, dando a conhecer as estratégias de repressão violenta exercidas pelo governo e, com isso, suscitar a condenação pública do mesmo e conseguir apoios de outros intervenientes sociais de peso. A mencionada concentração foi reprimida pela polícia militar através do uso de bombas de gás e armas de fogo - incluindo metralhadoras portáteis - e saldou-se com 72 estudantes detidos, vários feridos, dois com gravidade por arma de fogo, e um morto, o estudante "secundarista" Nélson Luiz Lima Souto, de 17 anos de idade, que foi alvejado com um tiro na cabeça, efetuado por agentes da polícia militar. Aludindo a declarações oficiais realizadas pelo general Niemeyer, responsável pela operação, a imprensa assegurou que a autêntica motivação da concentração tinha sido protestar contra a guerra do Vietnam e deu a entender que a fatalidade dos acontecimentos se deveu a uma postura pouco razoável, provocadora, inclusive violenta, da parte dos jovens, que se negaram a qualquer tipo de negociação, 
além da infiltração de um elemento estranho à massa estudantil na passeata, ao que se atribui a responsabilidade de ter iniciado o tiroteio que motivou a intervenção policial.

Os sucessos de Calabouço geraram, imediatamente, reações diversas em distintos pontos do país e a condenação por parte dos meios de comunicação, tal como se reflete num dos títulos de imprensa do dia 30 de março: "Morte do Estudante no Rio Provoca Repulsa General na Opinião Pública" (REDACÇÃO, 1968i). No dia seguinte ao assassinato de Nélson, em Brasília, como gesto de solidariedade para com os estudantes de Guanabara, desenvolveu-se uma manifestação de universitários, que foi duramente reprimida pelas forças de segurança, através de jatos de água, bastões, bombas de gás lacrimogéneo e disparos de armas de fogo, finalizando a confrontação com vários feridos, dois polícias com gravidade e um estudante alvejado com um tiro no peito. Em Porto Alegre, nesse mesmo 29 de março, o reitor da Universidade Federal do Rio Grande do Sul (Ufrgs), onde há dias, devido ao corte nos orçamentos universitários, os estudantes de algumas faculdades estavam em greve geral, decidiu suspender durante uma semana as atividades universitária, pois a crise estudantil "ameaçava agravar-se, adquirindo também aspetos políticos, em vista da repercussão dos acontecimentos no Rio de Janeiro" (REDACÇÃO, 1968j): Apesar disso, o denominado Diretório Central de Estudantes Livre conseguiu levar a cabo uma manifestação em protesto contra os mencionados cortes, a morte de Nélson e a iminente nomeação de Costa e Silva como Doctor Honoris Causa pela Ufrgs. E também na capital do Rio Grande do Sul, a União Gaúcha dos Estudantes Secundários (Uges), fez circular uma nota oficial na qual protestavam contra o assassinato do estudante Nélson e pelas ameaças das autoridades de reprimir violentamente qualquer manifestação estudantil.

Mas foi no Rio de Janeiro onde as reações Ali, durante o velório do "secundarista", em companhia de personalidades das artes, da cultura e da política, congregaram-se mais de 5.000 estudantes, que declararam à imprensa terem sido testemunhas de terem visto o "comandante da escolta da Polícia Militar dar ordem aos policiais para que atirassem sobre os estudantes que manifestavam preocupações pela péssima qualidade da comida no Calabouço e ainda pela paralisação das obras do prédio do restaurantes e fizeram sentir com maior intensidade." (REDACÇÃO, 1968i). Entretanto, mais de 1.000 estudantes reuniam-se, em caráter de assembleia, no Teatro a Arena da Universidade Federal do Rio de Janeiro (UFRJ), durante o qual manifestaram a sua repulsa em relação à violência exercida pelo regime, decretaram uma semana de luto e projetaram mais assembleias setoriais e greves nas diferentes faculdades da UFRJ e na Pontifícia Universidade Católica do Rio de Janeiro (PUCRJ). Por sua vez, as autoridades militares pediram a todas as emissoras de rádio que, com o intuito de evitar "manifestações exaltadas nas ruas da cidade", não realizassem transmissões sensacionalistas dos acontecimentos do dia anterior e do funeral do estudante (Fig. 01). O ministro da Justiça, Gama e Silva, em declarações realizadas à imprensa, insistia nos esforços que estavam a ser realizados pelas autoridades para clarificar o "doloroso e lamentável acontecimento" de Calabouço, no qual o governo compreendia e respeitava os sentimentos e as motivações dos estudantes e que não se podia tolerar "nem agitação nem repressão policial em termos de violência desnecessária, a que, muitas vezes, como na tarde de ontem, conduz ao sacrifício inútil de uma preciosa vida e, em consequência, um estado emocional da população" (REDACÇÃO, 1968i); Não obstante, assinalou que as autoridades não deveriam "permanecer indiferentes aos 
episódios que possam gerar crises injustificadas ou artificiais, visando envolver a opinião pública". (REDACÇÃO, 1968i).

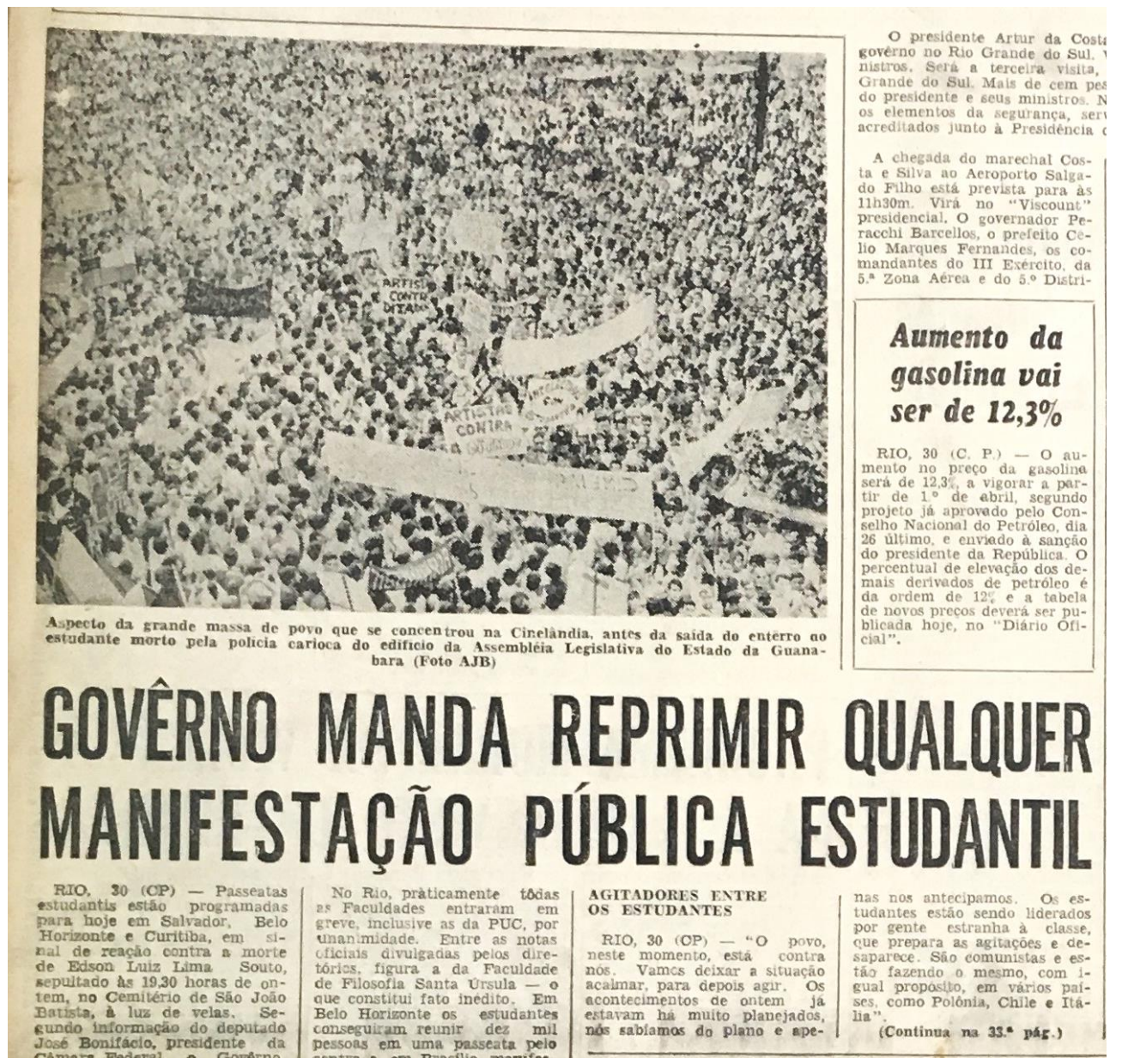

Figura 01 - Concentração estudantil em Cinelândia, antes do funeral de Nelson Luiz Lima Souto.

Fonte: Correio do Povo, edição de 31 de março de 1968.

Durante os dias seguintes, o "efeito Calabouço" gerou novas, maiores e mais intensas manifestações de indignação, protestos estudantis contra o assassinato de Nélson e o progressivo endurecimento da repressão policial. No dia 30 de março, no Rio de Janeiro, todas as faculdades da UFRJ e da PUCRJ declararam-se em greve; Em Salvador e Curitiba, programaram-se passeatas; Em Belo Horizonte, concentraram-se 10.000 estudantes; Em Brasília, uma passeata de mais de 10.000 pessoas, na qual participaram alguns deputados, terminou em duros confrontos entre a polícia e os estudantes, com um saldo de 20 feridos e 70 estudantes detidos. Entretanto, o ministro Gama e Silva enviou um telegrama- publicado integralmente nos diários - a todos os governadores, ordenando que adotassem "todas as medidas preventivas necessárias para impedir a participação ou infiltração daquele elementos, estando o Governo Federal decidido a manter e a preservar a qualquer custo a ordem e a segurança internas, como é de seu dever constitucional e exigem os superiores interesses e a desejada paz do povo brasileiro" (REDACÇÃO, 1968a). Apesar das advertências, no dia 1 de abril registaram-se novos e violentos choques entre a polícia e os estudantes em Goiânia, Brasília e Rio de Janeiro. Na última localidade, as hostilidades, que contaram com a intervenção do exército, deixaram um rasto de dois 
mortos, 60 civis e 39 polícias feridos, e 321 pessoas detidas e levadas à prisão, foram relatados como se de um ambiente de guerra se tratasse:

Divididos em grupos numerosos, que ocupavam as esquinas e fugiam quando a
policia disparava bombas de gás lacrimogénio, os estudantes transformaram o
centro da cidade num campo de guerrilhas, pois alguns estevam armados e
balearam os policiais. O governador da Guanabara declarou-se sem condições para
manter a ordem e pediu o auxílio do I Exercito [...] grupos de estudantes mais
exaltados depredaram um carro e incendiaram um outro [...] um choque entre
policiais e estudantes durou mais de meia hora. Os policiais foram recebidos a pau
e pedra pelos estudantes [...] Na Cinelândia houve violentos tiroteios e dezessete
PM foram baleados por estudantes [...]. (REDACÇÂO, 1968d).

No dia seguinte, a 2 de abril, as ações de protesto estudantis e a repressão das mesmas persistiram e alguns pontos do país. Em Goiânia, houve forte repressão de uma concentração estudantil que tinha lugar na Catedral Metropolitana, que finalizou com dois estudantes feridos por balas devido aos disparos efetuados pela Polícia Militar. Em Belo Horizonte, tiveram lugar confrontos à base de pedradas e bombas de gás lacrimogéneo entre uns e outros. Em Brasília, enquanto a Polícia Militar, convencida de que os estudantes guardavam um arsenal de bombas Molotov, preparava um assalto à Universidade, os docentes manifestavam-se condenando a violência exercida pelo governo para controlar a questão estudantil. Em São Paulo, onde as manifestações estudantis foram permitidas, desde que se desenvolvessem pacificamente e dentro da lei e ordem, sob ameaça de que os agentes federais deteriam os infratores e os enquadrariam na Lei de Segurança Nacional, cerca de 2.000 estudantes do ensino secundário concentraram-se no Bairro da Lapa. E, em Porto Alegre (Fig. 02), teve lugar uma passeata agitada e com inúmeras pessoas, com intensos distúrbios, que foram apresentados, através de palavras e imagens, como se a cidade se tratasse de um campo de batalha e os estudantes como elementos perigosos, especialistas em táticas de guerra de guerrilhas, capazes de criar as suas próprias armas e como antipatriotas subversivos e simpatizantes da casa do Viet Cong:

Grupos de estudantes universitários, secundaristas e elementos não ligados aos meios estudantis, mas que se aproveitaram da situação para incrementar a desordem, formando pequenos contingentes realizaram uma série de manifestações no centro da cidade [...] Enquanto uma turma agia num local, outra já desencadeava sua ação predatória em outro, tentando movimentos dispersivos para abrir várias frentes e, assim, perturbar a ação policial. $O$ fato mais grave foi o lançamento de uma bomba de fabricação caseira, conhecida como 'coquetel molotov' [...] Dando uma mostra de que suas intenções eram completamente alheias aos problemas estudantis, os manifestantes queimaram o retrato do marechal Costa e Silva [...] enquanto outros, portando grandes bandeiras vietcongs, tentavam realizar ataques relâmpagos [...] A rua dos Andradas era percorrida, de ponta a ponta, por policiais militares, os quais portavam bombas de gás lacrimogêneo. (REDACÇÃO, 1968e). 


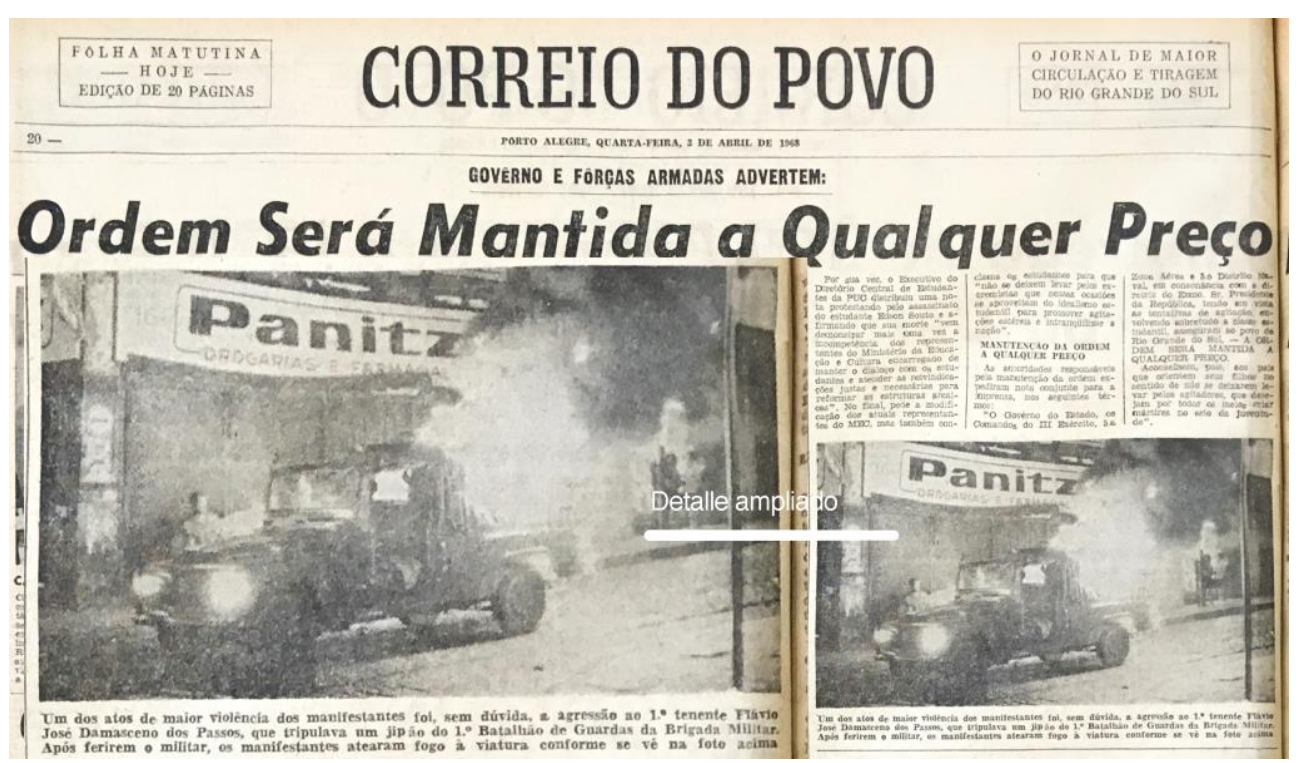

Figura 02 - Efeitos das manifestações estudantis em Porto Alegre.

Fonte: Correio do Povo, edição de 3 de abril de 1968.

No dia 4 de abril, por motivo da missa do sétimo dia da morte de Nélson, celebraram-se ofícios religiosos em distintas cidades do país, sob a sombra da ameaça de um possível estado de exceção. No Rio de Janeiro, realizou-se na Igreja da Candelária, na qual se juntaram cerca de 1.000 pessoas e um número muito superior nas imediações, na sua maioria estudantes, sob uma estreita vigilância das forças de ordem pública, que tinham destacado um amplo dispositivo de controlo e segurança - que incluía helicópteros e tanques - no lugar do evento e noutros pontos da cidade, que adquiriu um aspeto bélico. Apesar do ambiente tenso, a cerimónia e a concentração popular desenvolveram-se de forma pacífica, pelo menos, até ao final da missa. Nesse momento, de forma repentina, deu-se uma carga do esquadrão de cavalaria da Polícia Militar contra os congregados, enquanto os dispositivos da Divisão de Ordem Política e Social (Dops) chegavam para ajudar os primeiros. Inicialmente, os alvos principais eram os estudantes, no entanto, a atenção dirigiu-se também para os jornalistas encarregados de cobrir a missa, que iam registando a violência exercida pelas autoridades contra os estudantes. Estes confrontos, que duraram mais de duas horas e que se estenderam a espaços urbanos adjacentes, contaram vários feridos e mais de 240 estudantes detidos.

Durante esses dias, misturados com os factos, continuou a construir-se a narrativa dos acontecimentos - por vezes confusa - da perspectiva do governo, que foi filtrada aos diários através de seletivas declarações, comunicados e conferências de imprensa, que contribuíram para aumentar o alarme social. Nestas, insistiu-se em duas questões: a primeira, na rápida atuação do governo e na eficácia das forças de segurança que, apesar de tudo, conseguiram conter as ocorrências e restaurar a "tranquilidade prometida à população"; A segunda, no caráter subversivo das mobilizações estudantis, que foram despojadas de qualquer sentido íntimo e sincero, desenvolvendo a tese da "infiltração". A este respeito, as informações dadas à imprensa pelos serviços de informação e segurança nacional responsabilizaram das manifestações, concentrações e passeatas elementos "nitidamente comunistas" que, infiltradas - "que prepara as agitações e desaparece"- entre os estudantes, tentavam "retornar o país à desordem que precedeu à revolução de março" (REDACÇÃO, 1968g). Além disso, considerou-se que os "distúrbios" entre os estudantes e 
a polícia militar, que se registaram nas principais capitais do país, respondiam a um "plano geral de agitação [...] de orientação comunista" (REDACÇÃO, 1968g) para perturbar a ordem e desestabilizar o país: "São comunistas e estão fazendo o mesmo, com igual propósito, em vários países, como Polónia, Chile e Itália” (REDACÇÃO, 1968f). Os líderes estudantis, por sua vez, foram retratados como elementos perigosos para a segurança nacional, pois dispunham de ligações com políticos da oposição exilados no Uruguai, com líderes sindicais, com dirigentes do Partido Comunista e com comandos altamente qualificados em técnicas de "guerrilhas urbanas". Razões pelas quais a atividade estudantil deveria deixar de ser considerada como uma questão meramente universitária. 0 comunicado emitido pelo ministro Gama e Silva do dia 1 de abril, pode ser especialmente esclarecedor:

[...] as autoridades federais estão seguramente informadas de que conhecidos agitadores políticos suspeitos, pessoas justamente punidas pela Revolução e comunistas notórios, estão se aproveitando dessa situação e pretendem orientar as manifestações estudantis com o objetivo de atingir as autoridades constituídas, provocar alteração da ordem de atentar contra o patrimônio público e particular e o regime democrático. De outro lado, adversários do atual governo, inconformados com o regime no País e que é de liberdade, de respeito e de dignidade da pessoa humana e da verdadeira justiça social, a pretexto de se solidarizarem com os estudantes, querem apenas tirar vantagens políticas, a custo do ideal da juventude. (REDACÇÃO, 1968a).

Os sucessos de Calabouço e a sua onda expansiva não provocaram apenas reações entre os estudantes. Também repercutiram noutros intervenientes sociais: os grupos políticos, a Igreja e o quarto poder. Em primeiro lugar, geraram fricções no seio do governo: Por um lado, a "linha dura", que responsabiliza aquele que suscitar na juventude maiores receios e desconfiança face aos militares, reclamava do mesmo uma posição mais clara e contundente para acabar com as desordens por parte dos estudantes, de modo que não se chegasse à situação de ter de "reagrupar como em março de 1964, para defender a integridade da democracia, o povo e suas famílias, contra os comunistas" (REDACÇÃO, $1968 \mathrm{~g})$. Por outro lado, a "crise estudantil" foi objeto de numerosos e intensos debates na Câmara dos Deputados e do Senado do país, assim como em Assembleias Legislativas de diversos estados que chegaram a dedicar sessões completas ao assunto.

Os representantes da Aliança Renovadora Nacional (Arena) - partido do governo reforçaram a narrativa oficial dos acontecimentos, reafirmando a contenção, o critério e o bem-fazer das forças de ordem público na hora de lidar com os protestos dos estudantes, insistindo na tese de "infiltração" entre as massas juvenis de "elementos subversivos" e questionando, inclusive, a existência de um movimento estudantil real. Por sua vez, os líderes do Movimento Democrático Brasileiro (MDB) - partido da oposição -, além de denunciar energicamente a violência desproporcionada exercida sobre os estudantes e de acusar o governo de falta de diálogo e de querer utilizar estes conflitos para declarar o estado de exceção, ofereceram uma imagem distinta das mobilizações estudantis. Assim, apresentaram estes movimentos como parte de um cenário internacional mais amplo e fruto de uma guerra geracional, situados na vanguarda da luta pela liberdade - "nada mais que isso" -, que, no caso do Brasil, deviam ser interpretados como atos de afirmação da juventude em prol de um país mais livre, independente e democrático e como sintomas da insatisfação e o mal-estar dos estudantes devido à política educativa desenvolvida pelo 
governo, especificada no corte do financiamento, nas más condições materiais, nas intervenções das universidades e no processo de "moralização das mesmas".

Em segunda instância, algumas personalidades e setores destacados da Igreja Católica, como o Arcebispo de Goiânia, a Curia Metropolitana de Guanabara e a Associação de Educação Católica da Guanabara, ainda que com um discurso que mostrava clara adesão à "revolução de 64" e que reforçava a tese de "infiltração" de "elementos subversivos" entre a juventude suportada pela narrativa oficial, condenaram contundentemente os "excessos" e a "violência" - qualificada de "sacrílega arrogância" exercia pela Polícia Militar e pela DOPS durante as concentrações, manifestações, passeatas e celebrações religiosas, e também que o luto, a morte e a dor que tinham gerado foram objeto de exploração político-partidária. Por outro lado, o discurso público da lgreja mostrou-se solidário com a causa dos jovens, particularmente dos estudantes, considerados o futuro o país - não deteriorada pelas consequências do período prérevolucionário" - e apelava ao diálogo e à compreensão mútua, à análise das causas da insatisfação e frustração, como únicas vias para conseguir resolver o conflito, pois uma situação de violência e repressão sustentadas "leva a consciência dos juvenis a suspeitar de que não há no país liberdade para uma digna manifestação de pensamento". (REDACÇÃO, 1968h).

O quarto poder, por sua vez, também tomou posição, desde o princípio, perante a questão estudantil. Para o qual utilizou uma linguagem violenta e articulou um discurso duro, por vezes, ambíguo e confuso, que oscilou entre a defesa do governo surgido depois da "revolução de 64" e a denúncia dos "excessos" violentos este para manter a ordem e a paz sociais, e a compreensão da indignação dos estudantes e a crítica aos mesmos pelos seus abusos. Assim, distinguiu-se entre as mobilizações estudantis legítimas, desenvolvidas pacificamente e motivadas por situações objetivamente criticáveis - "a morte de um estudante"-, e aquelas que respondiam aos interesses espúrios de agentes alheios - infiltrados", "comunistas", "falsos líderes" e políticos de "esquerda" - aos setores estudantis - "aliás não só no Brasil como em todo o mundo" - (EDITORIAL, 1968b). Neste caso, ao não ser uma questão estritamente universitária, poderiam ser justificadas reações mais contundentes por parte do governo para manter "suficiente tranquilidade e efetivas condições para se trabalhar, produzir e forjar a grandeza da Pátria", mas sempre dentro "da lei e sob signo do respeito aos direitos inalienáveis da pessoa humana" (EDITORIAL, 1968b), tal como tinha atuado o serviço de segurança nacional, "a um tempo capaz e hábil, enérgica e sem demasias, temperando-se as medidas de prevenção e repressão indispensáveis com una nota de moderação, equilíbrio e serenidade" (EDITORIAL, 1968a). Um exemplo ilustrativo foi o texto "Baderna, Não", inicialmente publicado como editorial em O Estado de São Paulo:

[...] a situação criada na Guanabara com a morte brutal de um estudante foram plenamente justificadas pelos fatos [...] Depois do que passou nas ruas de Brasília na noite de anteontem não é mais possível duvidar-se de que entre os estudantes manobram elementos empenhados em perturbar a ordem, forçando o Governo a responder à violência com a violência [...] O povo da Guanabara deu anteontem uma grande lição de civismo ao País. Já em Brasília a coisas vieram a correr de modo totalmente diferente. Aí não havia o menor motivo para que a vida normal da cidade fosse alterada. E, contudo, ocorreram incidentes em cadeia, registrando-se cenas verdadeiramente degradantes. A infiltração de elementos subversivos, que tanto temíamos, teve uma influência decisiva [...] quando alguns agitadores 
hastearam [...] a bandeira do vietcong ficou patente que o controle das manifestações passara das mãos dos estudantes as de gente interessada em atingir objetivos políticos alheios ao que passara no Rio de Janeiro e aos interesses da classe estudantil em geral [...] Mas o que não podemos também é fechar os olhos à realidade e permanecer indiferentes enquanto agitadores hábeis, ao serviço do comunismo internacional, mobilizam os seus desorientados companheiros para atos de puro vandalismo e de subversão completa da ordem [...] O dispositivo policial e militar de Brasília deu mostras de uma calma muito grande, mesmo quando abertamente desafiado. Mas há limites para tudo [...] É o que os estudantes - de Brasília e de todo o País- devem compreender. Ir atrás das palavras de ordem desses falsos lideres e dar ouvidos as tiradas demagógicas dos parlamentares de esquerda festiva, que logo se uniram aos promotores da desordem, é oferecer ao governo o pretexto para uma repressão que, afinal, ele teme mais do que deseja. $O$ Executivo não tolerará a repetição de tumultos como os de Brasília, a Nação 'in totum' os repele [...] Para os estudantes, a alternativa é clara: ou seguem o exemplo que a cidade do Rio de Janeiro ofereceu [...] ou enveredam pelo caminho da baderna, e suportarão todas as consequências dessa atitude negativa. (REDACÇÃO, 1968c).

Um título publicado a 6 de abril anunciou que, ainda que persistissem algumas greves, o "Ambiente Estudantil Volta à Calma Após a Agitação dos Últimos Dias" (REDACÇÃO, 1968b). E assim pareceu ser, pois, a partir de então, até meados de junho, a atividade estudantil desenvolvida pelo país pareceu diminuir de dimensões e intensidade, tal como fez a repressão policial e militar, devido à mudança de tática realizada pelo governo, agora mais propensa ao diálogo, pelo menos, aparentemente. Não obstante, enquanto continuavam a chegar notícias do exterior acerca das mobilizações estudantis, especialmente do maio francês, continuaram a registar-se concentrações, ocupações, greves, manifestações e passeatas, cada vez com maior frequência, em diversos pontos do país, resolvidas, a maioria das vezes, de forma pacífica e, em ocasiões, reprimidas através do uso da violência chegando ao seu ponto culminante em junho de 1968 com a Passeata dos Cem Mil, sucedida no Rio de Janeiro. Esta foi, possivelmente, o princípio do fim da resistência estudantil de massas face à ditadura militar, que poucos meses mais tarde decretou o Al-5 e, com este, inaugurou uma nova fase evolutiva o governo autoritário com a sua política repressiva. Contudo este já é outro capítulo da História.

\section{Conclusões}

Os estudantes universitários ocuparam, durante o primeiro trimestre de 1968, um considerável espaço na esfera pública brasileira, sendo notícia na imprensa quase diariamente. A diversidade geopolítica - nacional e internacional - das mobilizações estudantis, o desenvolvimento quase sincrónico das mesmas, as semelhanças nos estilos, formas e lugares da sua ação, assim como o substrato comum das motivações, contribuíram para gerar uma particular comunidade imaginada de amplas dimensões, a dos jovens universitários em ação, que transcendeu a dos setores e ultrapassou os limites físicos dos espaços onde se desenvolveu a trama.

Contudo a imagem desta comunidade oferecida ao "cidadão comum" pela imprensa diária foi complexa, em ocasiões contraditórias. Embora o discurso oficial filtrado através da imprensa tenha enfatizado e inclusivamente reduzido todo o mal-estar estudantil relativamente ao problema do financiamento das universidades, as motivações e as reivindicações estudantis canalizadas pela imprensa diária cobriram um amplo espetro, destacando a guerra do Vietnam, a melhora das condições materiais e infraestruturas das 
universidades e, muito especialmente, o caráter ditatorial do governo da nação e de todas as suas instituições, a violência e a repressão por este exercidas.

Não obstante, salvo algumas e pouco destacadas exceções que aprofundaram a fundo a "questão estudantil", os jovens universitários apresentaram-se como um grupo revolucionário, organizado, pouco razoável e violento, cooptado e controlado por células comunistas infiltradas, aliado à oposição que operava desde o exílio, definitivamente, como uma ameaça para a ordem e paz sociais instauradas após a "revolução de 64". Este discurso, embora tenha sido constante, adquiriu especial relevância durante os momentos de maior atividade estudantil e de intensa repressão e violência exercidas pelo governo, potenciado pelo aumento dos níveis de alarme social, através da ameaça com a instauração do estado de exceção e da militarização da vida civil - que se tornou realidade em dezembro de 1968, com a promulgação do Al-5 - e através de crónicas minuciosas, nas quais vinham contidos números de feridos, mortos e detidos e se ofereciam detalhes táticos - tanto de estudantes como de forças de ordem pública -, as ruas e praças convertiam-se em cenários de batalhas e o estilo da narrativa adquiria traços próprios das crónicas e reportagens de guerra.

A linguagem e os discursos associados à "questão estudantil" adquiriram alguns rasgos próprios de estilos totalitários. A "tese da infiltração", desenvolvida pelo governo e suportada pelos diários, contribuiu para criar uma ampla, difusa e polivalente categoria de inimigo, etéreo e omnipresente, sempre à espreita e capaz de estar e não estar. Esta mesma teoria, que implicava uma ação externa e alheia despojava os movimentos de estudantes da sua especificidade, autonomia e legitimação, ao mesmo tempo que os vinculava diretamente ao comunismo - inimigo exterior e interior número um do país - e, com isso, ao deixar de ser uma questão estudantil e ao converter-se num assunto de interesse para a segurança nacional, justificava ou legitimava, até certo ponto, o avanço violento do governo. Para além disso, a imagem dos estudantes vinculada à projeção de uma persistente e alargada sombra do estado de exceção, o alarme social e o medo que inspirava, além de paralisar o "cidadão comum" reforçar a ideia de movimento estudantil como um grupo perigoso, feroz, digno de ser temido, contribuiu a apresentá-los como responsáveis do caos, pela destruição material, pela violência e pelos incómodos sofridos por esse mesmo "cidadão corrente".

Por sua vez, a linha editorial do Correio do Povo, manifestada nos artigos de opinião, editoriais, estrutura e disposição das informações, assim como a seleção de títulos, reforçou as teses e os discursos oficiais. As crônicas, notícias e resumos informativos, repletos de testemunhos, declarações e transcrições de documentos, também fizeram eco de uns e outros, contudo oferecendo uma imagem mais viva e ampla. Estas últimas secções, aparentemente objetivas, imparciais, fidedignas, precisas, frias e sem interpretações, desempenharam um papel fundamental, pois permitiram filtrar ao grande público a extensão e intensidade da repressão e da violência exercidas pelo governo sobre os estudantes, uma gama mais ampla de motivações e reivindicações dos últimos, oferecer uma imagem de vontade de diálogo e negociação por parte dos mesmos, assim como manifestar e canalizar, ainda que tímida e ciosamente, a condenação, a repulsa e indignação da opinião pública.

Tudo isto, apesar da última consideração, pode ser dado como outro exemplo significativo dos processos de transformação, em conjunturas ditatoriais, do chamado 
quarto poder em complexas extensões dos restantes que, sem perder a sua capacidade de gerar correntes de opinião pública, deixa de ser catalisadora da mesma, para contribuir para a construção e reforço de uma narrativa da realidade de acordo com um particular interesse público, das aspirações de grupos de poder maioritários - exclusivos e excludentes - que são consideradas - por si próprios - dignas de serem vistas e ouvidas em público. $\mathrm{O}$ que, unido aos mecanismos de censura e censura sem censuras de diferente índole, assim como aos já referidos usos da linguagem totalitária e às pretendidas e aparentes objetividade e imparcialidade da imprensa, refletidas nos estilos e modos de articular narrativas, impessoais, fidedignas, precisas, sem interpretações, com constantes testemunhos, declarações e transcrições de documentos, puderam transformar os jornais em instrumentos propagandísticos mais subtis, refinados e eficazes que os especificamente desenhados para tal propósito, cuja verdade só podia ser desmentida pela via da experimentação direta das pessoas, em condição de testemunho de outras verdades, das que comprovam, porque as viram e ouviram. Isto pôde significar, a fim de contas, mais uma forma totalitária de neutralizar a capacidade de ação dos cidadãos e, com isso, também de uma parte substancial da liberdade.

\section{Referências}

ANDERSON, Benedict. Comunidades imaginadas. México, D. F.: Fondo de Cultura Económica, 1993.

ARENDT, Hannah. La condición humana. Barcelona: Paidós, 1993.

BARBOSA, Marialva. História cultural da imprensa. Brasil, 1900-2000. Rio de Janeiro: Mauad X, 2007.

BRUNO-JOFRÉ, Rosa. Educación popular en América Latina durante la década de los setenta y ochenta: una cartografía de sus significados políticos y pedagógicos. Foro de Educación, v. 14, n. 20, p. 429-451, 2016.

CAGNOLATI, Antonella. Ma che colpa abbiamo noi? Mass-media e protesta studentesca. In: BETTI, Carmen; CAMBI, Franco. II '68: Una rivoluzione culturale tra pedagogia e scuola. Milano, 2011.

CAREY, Elaine (Ed.). Protests in the Streets: 1968 Across the Globe. Indianapolis: Hackett Publishing, 2016.

CARRILLO-LINARES, Alberto. Universidades y transiciones políticas: el caso español en los años 60-70. Espacio, Tiempo y Educación, v. 2, n. 2, p. 49-75, 2015.

CUNHA, Diogo. O campo intelectual no Brasil nas décadas de 1960 e 1970: a "estrutura cultural conservadora", as universidades e as esquerdas. História Unicap, v. 3, n. 5, p. 100-120, 2016.

CUNHA, Luiz Antônio. A universidade crítica: o ensino superior na república populista. São Paulo: Editora UNESP, 2007.

DE MORAES FREIRE, Silene. Movimento estudantil no Brasil: lutas passadas, desafios presentes. Historia de la Educación Latinoamericana, n. 11, p. 131-146, 2008.

DELGADO, Sandra; GAUTREAUX, Michelle; ROSS, E. Wayne. Students in revolt: The pedagogical potential of student collective action in the age of the corporate university.

Knowledge Cultures, v. 4, n. 6, p. 141-158, 2016.

EDITORIAL. Govêrno, Rio Grande e Ordem. Correio do Povo. 2 abril, 1968a. 
. Ordem Sem Violências. Correio do Povo. 31 março, 1968b.

ÉSTHER, Angelo Brigato. Que universidade? Reflexões sobre a trajetória, identidade e perspectivas da universidade pública brasileira. Espacio, Tiempo y Educación, v. 2, n. 2, p. 197-221, 2015.

FAGUNDES, Pedro Ernesto. Universidade e repressão política: o acesso aos documentos da assessoria especial de segurança e informação da Universidade Federal do Espírito Santo (AESI/UFES). Revista Tempo e Argumento, v. 5, n. 10, p. 317-346, 2013.

FERNANDES, Luan Aiuá Vasconcelos. A repressão contra os professores nas universidades latino-americanas durante a ditadura: os casos da UFMG (1964-1969) e da UTE (1973-1981). Cuadernos Chilenos de Historia de la Educación, v. 2, n. 2, p. 86120, 2015.

FONTES, Edilza Joana Oliveira; ALVES, Davidson Hugo Rocha. A UFPA e os Anos de Chumbo: A administração do reitor Silveira Neto em tempo de ditadura (1960-1969).

Revista Tempo e Argumento, v. 5, n. 10, p. 258-294, 2013.

FRANCO, Isaura Melo; SOUZA, Sauloéber Tarsio de. Estudantes no Pontal Mineiro e ditadura militar na década de 1960. Revista Tempo e Argumento, v. 5, n. 10, p. 347-372, 2013.

GROVES, Tamar. Teachers and the Struggle for Democracy in Spain, 1970-1985. New York: Palgrave macmillan, 2014.

HALBWACHS, Maurice. La memoria colectiva. Zaragoza: Prensas Universitarias de Zaragoza, 2004.

HALL, Stuart. Los hippies: una contra-cultura. Barcelona: Anagrama, 1970.

HERNÁNDEZ HUERTA, José Luis. La rivolta studentesca brasiliana del '68.

Considerazioni a partire dalla stampa quotidiana. In: TODARO, Letterio. Pedagogia, istanze di emancipazione trasformazioni dell'immaginario educativo tra gli anni '60 e '70 del Novecento. Roma, 2017.

. Metáforas de la prensa diaria para la historia de la educación. Del "largo '68" al fin de la "tercera ola" en la Europa mediterránea e Iberoamérica. História da Educação, v. 22, n. 54, 2018.

IGELMO ZALDÍVAR, Jon. Desescolarizar la vida. Ivan Illich y la crítica de las instituciones educativas. Madrid: Enclave de Libros, 2016.

KLEMPERER, Victor. La lengua del Tercer Reich. Barcelona: Minúscula, 2001.

MAIA, Tatyana de Amaral. Civismo e cidadania num regime de exceção: as políticas de formação do cidadão na ditadura civil-militar (1964-1985). Revista Tempo e Argumento, v. 5, n. 10, p. 182-206, 2013.

MARKARIAN, Vania. Uruguay, 1968: Student Activism from Global Counterculture to Molotov Cocktails. Berkeley: University of California Press, 2017.

MARWICK, Arthur. The Cultural Revolution of the Long Sixties: Voices of Reaction, Protest, and Permeation. The International History Review, v. 27, n. 4, p. 780-806, 2005.

MATTOS, André Luiz Rodrigues de Rossi. Uma História da UNE (1945-1964). Campinas, SP: Pontes Editores, 2014.

MOTTA, Rodrigo Patto Sá. As Universidades e o Regime Militar. Cultura política brasileira e modernização autoritária. Rio de Janeiro: Zahar, 2014. 
NETTO, José Paulo. Pequena História da Ditadura Brasileira (1964-1985). São Paulo: Cortez Editora, 2014.

OFER, Inbal; GROVES, Tamar (Eds.). Performing Citizenship. Social Movements across the Globe. New York: Routledge, 2016.

OFFE, Claus. New Social Movements: Challenging the Boundaries of Institutional Politics. Social Research, v. 52, n. 4, p. 817-868, 1985.

POERNER, Arthur José. 0 poder jovem. História da participação política dos estudantes brasileiros. Rio de Janeiro: Booklink, 2004.

REDACÇÃO. Alerta do Ministro da Justiça. Governador afirma que não permitirá quebra da ordem. Correio do Povo. 2 abril, 1968a.

Ambiente Estudantil Volta À Calma Após A Agitação Dos Últimos Dias. Correio do Povo. 6 abril, 1968b.

Baderna, Não. Correio do Povo. 2 abril, 1968c.

Dois mortos e dezenas de feridos. Ocorreram Novos Choques Entre Polícia e Estudantes: Rio, Goiânia e Brasília. Correio do Povo. 2 abril, 1968d.

. Governo e Forças Armadas Advertem: Ordem Será Mantida a Qualquer Preço. Correio do Povo. 3 abril, 1968e.

. Govêrno Manda Reprimir Qualquer Manifestação Pública Estudantil. Correio do Povo. 31 março, $1968 f$.

2 abril, 1968g.

I Exército Entrou em Rigorosa Prontidão Por Ordem Ministerial. Correio do Povo.

. Manifestações Estudantis No País. Exército Assumiu Ontem O Policiamento de Goiânia. Correio do Povo. 3 abril, 1968h.

. Morte do Estudante no Rio Provoca Repulsa General na Opinião Pública. Correio do Povo. 30 março, 1968i.

. Reitor suspende por uma semana as atividades docentes na URGS. Correio do Povo. 30 março, 1968j.

RIBEIRO, Ana Paula Goulart. Modernição e concentração: a imprensa carioca nos anos 1950-1970. In: NEVES, Lúcia Maria Bastos P. das; MOREL, Marco; FERREIRA, Tânia Maria Bessone da C. História e imprensa: representações culturais e práticas de poder. Rio de Janeiro, 2006. p. 426-435.

RICOEUR, Paul. La memoria, la historia, el olvido. Madrid: Trotta, 2010.

ROCHA, Helenice. A Ditadura Militar (1964-1985) nas narrativas didáticas brasileiras.

Espacio, Tiempo y Educación, v. 2, n. 1, p. 97-120, 2015.

ROMANCINI, Richard; LAGO, Cláudia. História do jornalismo no Brasil. Florianópolis: Insular, 2007.

ROMÃO, José Eustáquio. Os frutos de Maio de 1968 - O Grito dos Silenciados. Historia de la Educación Latinoamericana, n. 11, p. 189-204, 2008.

ROSÚA, Mercedes. El archipiélago Orwell. Madrid: Grupo Unisón Producciones, 2001. ROTHEN, José Carlos. La reforma universitaria brasileña de 1968. Revista de la Educación Superior, v. 35, n. 1, p. 43-61, 2006.

SANFELICE, José Luis. A UNE na resistência ao golpe de 1964 e à ditadura civil-militar. In: MARCO, Jorge; SILVEIRA, Helder Gordim da; MANSAN, Jaime Valim. Violência e 
Sociedade em Ditaduras Ibero-Americanas no Século XX: Argentina, Brasil, Espanha e Portugal. Porto Alegre: EdiPUCRS, 2015. p. 61-78.

SODRÉ, Nelson Werneck. História da imprensa no Brasil. Porto Alegre: EDIPUCRS, 2011.

TAYLOR, Charles. Imaginarios sociales modernos. Barcelona: Paidós, 2006.

VAN DIJK, Teun A. Análisis del discurso ideológico. Versión, v. 6, p. 15-43, 1996.

. El análisis crítico del discurso. Anthropos, v. 186, p. 23-36,1999.

VIEIRA, Evaldo. A República Brasileira 1951-2010. De Getúlio a Lula. São Paulo: Cortez

Editora, 2015.

JOSÉ LUIS HERNÁNDEZ HUERTA é Doctor Europeus em Pedagogía pela Universidade de Salamanca (Espanha) e professor da Faculdade de Educação de Palencia, Departamento de Filosofía, Secção de Teoria e História da Educação, da Universidade de Valladolid (Espanha). Editor das revistas Foro de Educación y Espacio, Tiempo y Educación. Diretor do Grupo de Investigación Ágora de Educación (Universidade de Valladolid, Espanha), coordenador de Connecting History of Education Working Group y membro da equipe do Grupo de Investigación Reconocido Memoria y Proyecto de la Educación (Universidade de Salamanca, Espanha) e do I Grupo de Estudios Medievales y Renacentistas (Facultad de Educación Uned, España). Faz parte das sociedades científicas International Standing Conference on the History of Education (Ische), Sociedad Española de Historia de la Educación (Sedhe) e Sociedade Brasileira de História da Educação (Sbhe).

Endereço: Facultad de Educación de Palencia - Universidad de Valladolid - Av. Madrid, 44 34004 - Palencia - Espanha.

E-mail: jlhhuerta@mac.com

Recebido em 01 de outubro de 2017.

Aceito em 28 de novembro de 2017. 